\title{
Observations on the Nature of the Underlying Disorder and the Occurrence of Associated Plasma Transport Ab- normalities in a Patient with an Idiopathic Increase in the Plasma Thyroxine- binding Globulin*
}

\author{
Sidney H. Ingbar, Christine Waterhouse, and Paul Cushman $\dagger$ \\ (From the Thorndike Memorial Laboratory, Second and Fourth [Harvard] Medical Services, \\ Boston City Hospital, and the Department of Medicine, Harvard Medical School, \\ Boston, Mass., and the Department of Medicine, University of Rochester \\ School of Medicine and Dentistry, Rochester, N. Y.)
}

Since its discovery in 1952, much has been learned concerning the thyroxine $\left(\mathrm{T}_{4}\right)$-binding globulin of human plasma (TBG) [cf. Reviews $(1,2)]$. Although its concentration in plasma has not been directly measured and is presumably very low, the capacity of TBG to bind $T_{4}$ is readily measured and is normally about $20 \mu \mathrm{g}$ per $100 \mathrm{ml}$ of serum or plasma (1). Recently, several patients have been described in whom the $\mathrm{T}_{4}$-binding capacity of TBG is either greatly increased or decreased, apparently on a hereditary basis (3-8). Physiological studies in such patients have contributed much to a formulation of the role of this protein in the peripheral metabolism of $\mathrm{T}_{4}(3,5,7,8)$. On the other hand, little has been done to elucidate either the cause of the protein abnormality itself or the presence of associated abnormalities in other plasma transport proteins.

The availability of a patient with an apparently idiopathic increase in the $\mathrm{T}_{4}$-binding capacity of TBG has made possible further studies of this disorder. Since ceruloplasmin [cf. Review (9)] and the corticosteroid-binding globulin (transcortin) (10-14), like TBG (15-17), normally increase in concentration or binding activity in re-

* Submitted for publication June 29, 1964; accepted July 27, 1964.

Supported in part by research grant no. AM-00267-10 from the National Institute of Arthritis and Metabolic Diseases, Bethesda, Md., and in part by U. S. Public Health Service research grant no. FR 44-03 from the Division of Research Facilities and Resources, National Institutes of Health, Bethesda, Md.

$\dagger$ Present address: St. Luke's Hospital, New York, N. Y. sponse to pregnancy or to the administration of estrogenic hormones, studies of these three proteins, as well as the iron-binding globulin (transferrin), in the serum of this patient were conducted in the basal state and during administration of large doses of diethylstilbestrol. The responses of TBG and transferrin to an anabolic steroid, norethandrolone, were also assessed.

\section{Methods}

Case history. Patient F. H. (Strong Memorial Hospital no. 46-32-67), a 66-year-old white female, was first seen in 1958 and complained at that time of episodes of giddiness and vertigo, anxiety, tachycardia, and diaphoresis of about six months' duration. Weight loss, heat intolerance, tremor, and palpitations were denied. A goiter had been noted 40 years earlier and had not changed in the interim. The patient denied having received any iodine-containing or hormonal medication. Physical examination revealed the blood pressure to be $100 / 85$, the pulse rate 88 . The thyroid gland was diffusely enlarged, apparently without thrill, bruit, or nodules. There were no physical signs of hypermetabolism. Significant laboratory data included the following: BMR, $+12 \%,+3 \%$; thyroidal 24 -hour $\mathrm{I}^{131}$ uptake, $20 \%$, $22 \%$; serum protein-bound iodine (PBI), 11.2, 11.6, 10.6, $9.2 \mu \mathrm{g}$ per $100 \mathrm{ml}$.

In view of the increased $\mathrm{PBI}$, a trial of methimazole was initiated. At a dosage of $30 \mathrm{mg}$ daily, symptoms apparently cleared, but the PBI remained 9.0 and $9.2 \mu \mathrm{g}$ per $100 \mathrm{ml}$ after 8 months of treatment. When the dose of methimazole was increased to $40 \mathrm{mg}$ daily, clinical signs of myxedema appeared, and the PBI declined to $0.9 \mu \mathrm{g}$ per $100 \mathrm{ml}$. Methimazole was discontinued, and several weeks later, in May of $1960,5 \mathrm{mc}$ of $\mathrm{I}^{131}$ was administered. The patient was asymptomatic at this time and has remained so subsequently, although her thyroid decreased in size. In March 1961, laboratory tests revealed: BMR, - 7\%, - 5\%; PBI, $10.7 \mu \mathrm{g}$ per $100 \mathrm{ml}$; serum 
butanol extractable iodine, $8.8 \mu \mathrm{g}$ per $100 \mathrm{ml}$; 24-hour thyroidal $\mathrm{I}^{131}$ uptake, $38 \%$, decreasing to $5 \%$ after 7 days of treatment with $3,5,3^{\prime}$-triiodothyronine, $100 \mu \mathrm{g}$ daily.

In June 1961, an increase in the binding activity of TBG was considered as the possible cause of her abnormal PBI. Electrophoretic studies of her serum revealed the $\mathrm{T}_{4}$-binding activity of $\mathrm{TBG}$ to be greatly increased. In view of the persistently normal values for BMR and thyroidal $\mathrm{I}^{131}$ uptake, both before and after $\mathrm{I}^{131}$ therapy, and the normal thyroid suppression test, it would appear likely that the patient's persistently increased PBI was never due to thyrotoxicosis, but was, instead, a consequence of increased hormonal binding in the plasma.

In August 1962, the patient was admitted to the Strong Memorial Hospital to receive a 3 -week course of diethylstilbestrol, $30 \mathrm{mg}$ daily. The control cervical smear revealed no evidence of estrogenic effect. A progressive effect was noted during treatment, however, and was marked by the time diethylstilbestrol was discontinued. Withdrawal vaginal bleeding followed a few days thereafter.

The patient was readmitted in November 1962 to receive a 3 -week course of norethandrolone, $50 \mathrm{mg}$ daily. During the treatment period, serum glutamic-oxalacetic transaminase values increased from 20 to $60 \mathrm{U}$. Serum bilirubin upon completion of therapy was $1 \mathrm{mg}$ per 100 $\mathrm{ml}$. Balance studies performed during and after the treatment period revealed that norethandrolone induced significant nitrogen retention.

In July of 1963, the patient was readmitted for a second course of diethylstilbestrol treatment in order to verify the previously observed findings with regard to the effects of this agent on $\mathrm{T}_{\mathbf{4}}$-binding and to assess its effects on other plasma transport proteins.

Procedure. Thyroxine-binding capacities of TBG and thyroxine-binding prealbumin (TBPA) in serum were measured by methods described in detail earlier, employing paper electrophoresis in Tris-maleate buffer, $\mathrm{pH}$ 8.6 (7). Concomitantly, the distribution of tracer quantities of $\mathrm{I}^{131}$-labeled thyroxine, reflecting the binding of the endogenous hormone, was also assessed. Analyses for the proportion of unbound $T_{4}$ in serum were carried out by an equilibrium dialysis technique, recently described in abstract form (18), to be described in detail in a later communication. Serum PBI was measured by a modification of the method of Zak (19). Plasma $17-\mathrm{OH}$ corticosteroids were analyzed by the method of Peterson, Karrer, and Guerra (20), and transcortin concentrations by the method of Daughaday, Adler, Mariz, and Rasinski (14). Ceruloplasmin was measured by the method of Scheinberg and Morell (21). Serum iron-binding capacities were measured by the method of Peters, Biovanniello, Apt, and Ross (22).

\section{Results}

Results obtained are presented in Table I and Figure 1. In the basal state, the patient's PBI on

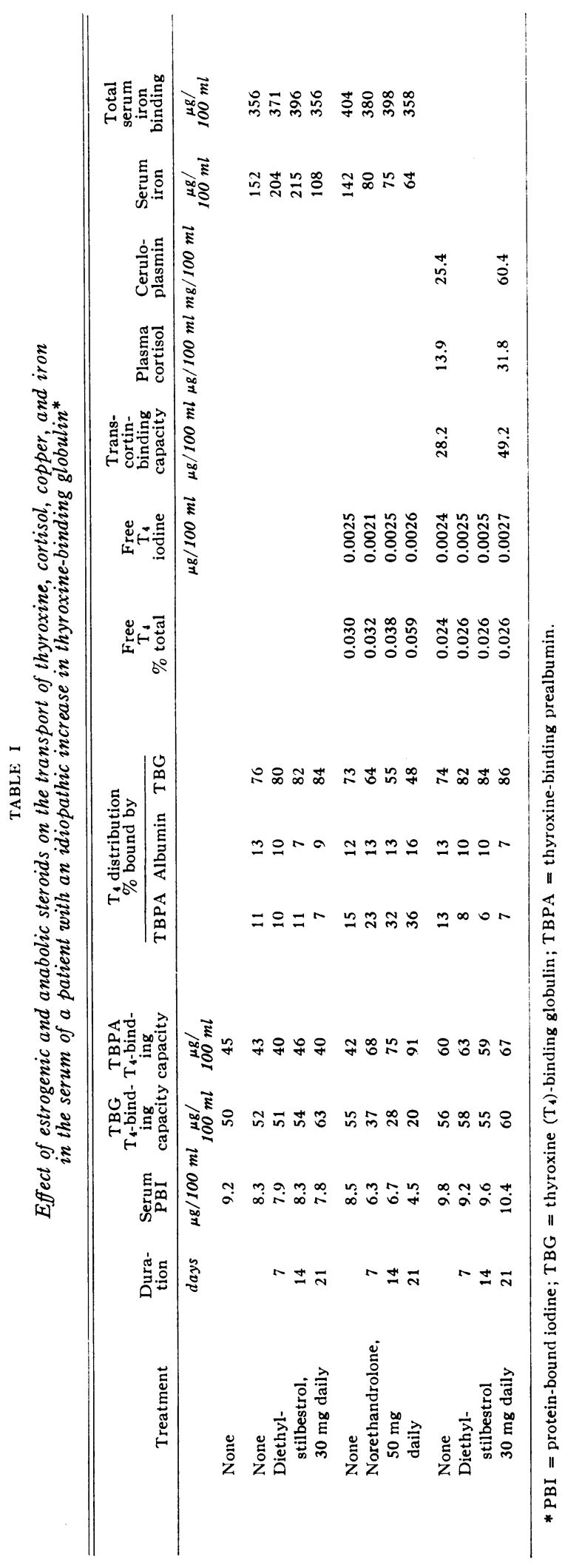


-.....-PBI $(\mu \mathrm{g} / 100 \mathrm{~mL})$

$x \longrightarrow x$ TBG Binding Copocity $\left(\mu g T_{4} / 100 \mathrm{~mL} \times 10^{-1}\right)$

$\Delta--\Delta$ Free $T_{4}\left(\%\right.$ total $\left.\times 10^{2}\right)$

$\leadsto$ Free $T_{4}$ lodine $\left(\mu \mathrm{g} / 100 \mathrm{~mL} \times 10^{3}\right)$
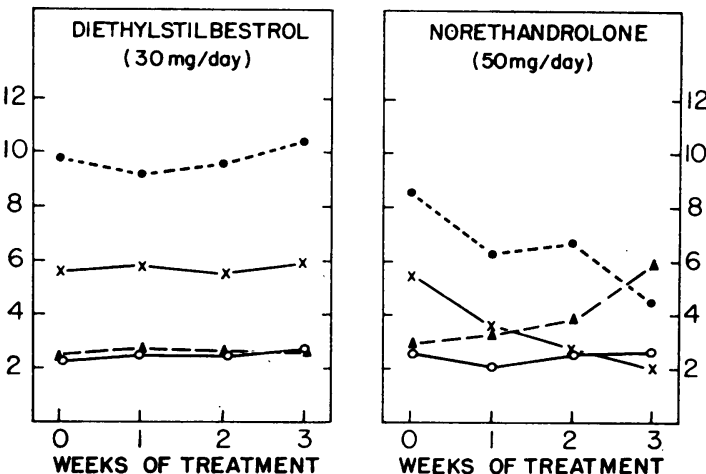

Fig. 1. EFFECT OF ESTROGENIC AND ANABOLIC STEROIDS ON THE TRANSPORT OF THYROXINE IN THE SERUM OF A PATIENT WITH AN IDIOPATHIC INCREASE IN THYROXINEBINDING GLOBULIN. $\mathrm{PBI}=$ protein-bound iodine $; \mathrm{TBG}=$ thyroxine $\left(T_{4}\right)$-binding globulin.

repeated determinations since June of 1961 ranged between 9.2 and 8.3 , averaging $9.0 \mu \mathrm{g}$ per $100 \mathrm{ml}$. Thyroidal $\mathrm{I}^{131}$ uptake and basal metabolic rate were within normal limits. Thyroxine-binding capacity of TBG, measured on four occasions during a 25 -month period, ranged between 50 and $56 \mu \mathrm{g}$ per $100 \mathrm{ml}$ of serum and averaged $54 \mu \mathrm{g}$ per $100 \mathrm{ml}^{1}$ The $\mathrm{T}_{4}$-binding capacity of TBPA was moderately decreased, averaging $47 \mu \mathrm{g}$ per $100 \mathrm{ml}$. Approximately $75 \%$ of endogenous $\mathrm{T}_{4}$ was associated with TBG, $15 \%$ with TBPA, and the remainder with albumin.

In control studies, the per cent of unbound or free thyroxine in the patient's serum was subnormal $(0.027$ and $0.024 \%)$ and was similar to the values seen during normal pregnancy. Values for the concentration of free $\mathrm{T}_{4}$-iodine, calculated as the product of the per cent of free $\mathrm{T}_{4}$ and the PBI, averaged $0.0024 \mu \mathrm{g}$ per $100 \mathrm{ml}$, well within the normal range.

Plasma 17-OH corticoid concentration (13 $\mu \mathrm{g}$ per $100 \mathrm{ml}$ ) and transcortin-binding capacity

\footnotetext{
1 By the methods employed in the present studies, normal values are: $\mathrm{T}_{4}$-binding capacity of TBG, $22 \mu \mathrm{g}$ per $100 \mathrm{ml}$ (range, 18 to 25 ); $\mathrm{T}_{4}$-binding capacity of TBPA, $140 \mu \mathrm{g}$ per $100 \mathrm{ml}$ (range, 100 to 200 ) ; distribution of a tracer concentration of labeled $\mathrm{T}_{4}$ (endogenous distribution), TBG, $45 \%$, TBPA, $40 \%$, albu$\min , 15 \%$; free $\mathrm{T}_{4}, 0.043 \pm 0.008 \%$ of total (mean $\left.\pm \mathrm{SD}\right)$; free $\mathrm{T}_{4}$-iodine, $0.0024 \pm 0.0007 \mu \mathrm{g}$ per $100 \mathrm{ml}$ (mean \pm SD).
}

$(28.2 \mu \mathrm{g}$ per $100 \mathrm{ml})$ were within normal limits, as was the concentration of ceruloplasmin (25.4 $\mathrm{mg}$ per $100 \mathrm{ml}$ ). Total serum iron-binding capacity was at the upper limit of the normal range (356 and $404 \mu \mathrm{g}$ per $100 \mathrm{ml}$ ), although serum iron was normal (152 and $142 \mu \mathrm{g}$ per $100 \mathrm{ml}$ ).

Response to diethylstilbestrol. During two separate 3-week trials of diethylstilbestrol, no significant change in the PBI, in the proportion of unbound $T_{4}$, or in the concentration of free $T_{4}{ }^{-}$ iodine in the serum occurred. The $\mathrm{T}_{4}$-binding capacity of TBG showed little, if any, response to estrogen administration. During the first trial, the binding capacity was $52 \mu \mathrm{g}$ per $100 \mathrm{ml}$ in the basal state and 63 per $100 \mathrm{ml}$ after 3 weeks of therapy. During the second trial, comparable values were 56 and $60 \mu \mathrm{g}$ per $100 \mathrm{ml}$, respectively.

The per cent of endogenous $\mathrm{T}_{4}$ bound by TBG increased slightly and that bound by TBPA decreased.

In contrast to these negligible changes in the binding of thyroxine, pronounced increases in the concentration of cortisol, transcortin, and ceruloplasmin occurred during administration of estrogen. Total serum iron-binding capacity and serum iron were not significantly affected.

Response to anabolic steroid. In contrast to the relative lack of change in $\mathrm{T}_{4}$-binding that occurred during administration of diethylstilbestrol, pronounced changes in $\mathrm{T}_{4}$-binding occurred during administration of norethandrolone. The thyroxine-binding capacity of TBG decreased to normal, the PBI to the lower limit of the normal range. Concomitantly, the proportion of unbound thyroxine increased to values slightly in excess of normal, with the result that the concentration of free thyroxine iodine remained essentially unchanged. The $\mathrm{T}_{4}$-binding capacity of TBPA increased from its low basal value, but did not come into the normal range. The proportions of endogenous $\mathrm{T}_{4}$ associated with TBG and TBPA, which in the basal state were increased and decreased, respectively, gradually came into or near the normal range.

Serum iron-binding capacity was not significantly altered, but serum iron concentration decreased. Binding capacities of transcortin and ceruloplasmin were not measured at this time. Nitrogen retention was observed during the treatment period. 


\section{Discussion}

Studies of the disturbance in protein metabolism that occurs in states accompanied by alterations in TBG are hampered by current inability to measure the concentration of this protein in the plasma. Thus, in those states designated as idiopathic increases or decreases in the binding activity of TBG, it is not known whether the actual concentration of protein is abnormal or whether its structure is altered in such a way as to change its molecular $\mathrm{T}_{4}$-binding capacity. Similar uncertainty applies both to the increases in $\mathrm{T}_{4}$-binding by TBG that occur during pregnancy or estrogen administration and to the decreases that are induced by androgenic or anabolic steroids. ${ }^{2}$

In the present patient, the $\mathrm{T}_{4}$-binding capacity of TBG, the PBI, and the per cent of free $\mathrm{T}_{4}$ in the serum were all within the range to be expected either during normal pregnancy or in response to large quantities of estrogen (15-17). Neither of these explanations of the abnormality was tenable, however, since the patient was postmenopausal and the cervical smear revealed no evidence of estrogenic effect. Thus, her disorder appears to merit the designation "idiopathic increase in TBG."

Although the patient's increased TBG could not be ascribed to estrogen, evidence was obtained that both genital and extragenital effects of estrogen could be elicited. Intense estrogenic effect on the cervix and vaginal bleeding followed administration and withdrawal, respectively, of diethylstilbestrol. In addition, this agent evoked an increase in the concentrations of transcortin and ceruloplasmin in the plasma, a response similar to that seen in normal individuals (9-14). Although the patient responded to estrogen in these respects, the patient's already increased TBG was unaffected by diethylstilbestrol in a dosage and duration that normally increase TBG greatly. Doses of anabolic steroid, sufficient to induce nitrogen retention, in contrast, lowered the TBG and PBI and increased the proportion of free $\mathrm{T}_{4}$

\footnotetext{
2 For purposes of brevity, an increase or decrease in the binding capacity of TBG will henceforth be referred to merely as an increased or decreased TBG, respectively. These terms, as herein used, do not indicate that the concentration of the protein is necessarily increased.
}

in the serum, a response similar to that elicited in normal subjects (23).

From these and other findings it is possible to draw several inferences concerning the nature of the underlying disorder in patients with idiopathic increase in TBG, at least to the extent to which this patient may be typical of others. It seems likely that the increased $\mathrm{T}_{4}$-binding by $\mathrm{TBG}$ in this patient's serum, and in other states associated with increased TBG, reflects an increase in the actual concentration of this protein. Such a change must result from increased synthesis or decreased degradation of the protein, or both. Although one cannot presently choose between these possibilities, it would appear that the factors which increased this patient's TBG were the same as those that normally increase TBG in response to estrogen. A pre-existing maximal activation of this mechanism would explain the failure of TBG to increase further when estrogen was administered. On the other hand, the contrary or antagonistic response to androgenic or anabolic steroids was apparently retained.

From the present studies it is additionally apparent that the abnormality in protein metabolism, evident in the increased TBG, was not general to other proteins whose concentrations in the plasma are normally increased by estrogens. Concentrations of ceruloplasmin and transcortin were normal in the basal state and, as might therefore be expected, demonstrated a normal increase in response to estrogen therapy.

In view of the existing data concerning transferrin, studies of this protein in the patient's serum were inconclusive. Concentrations of transferrin are usually increased during normal pregnancy, but there is considerable overlap between values usually found in pregnancy and the rather broad normal range [cf. Review (24)]. Furthermore, it is not certain whether the increase in the concentration of transferrin that occurs during pregnancy is due to a relative iron deficiency or whether transferrin is estrogen-responsive, like TBG, transcortin, and ceruloplasmin. Values for the total iron-binding capacity of the present patient's serum were at the upper limit of normal, and although no increase was elicited by diethylstilbestrol, it is not known whether this would normally be expected.

Finally, the present studies provide further evi- 
dence of the physiological consequences of $\mathrm{T}_{4}$-binding. It is generally agreed that although the proportion of free $T_{4}$ may vary in diverse states, the physiologically important variable is the concentration of free $T_{4}$ in the plasma. In the present patient, despite a substantial increase in the total hormonal concentration, the proportion of free hormone, not heretofore measured in this syndrome, was decreased. As a result, the concentration of free $\mathrm{T}_{4}$-iodine was normal, and this was associated with a normal metabolic state and normal thyroid function. When, on the other hand, the binding of $\mathrm{T}_{4}$ was decreased by norethandrolone and the proportion of free hormone increased, the hormonal concentration in the blood declined until the free $\mathrm{T}_{4}$-iodine was within the normal range and the patient remained metabolically normal. These findings strengthen further the now well-supported hypothesis that both the homeostatic mechanisms which regulate thyroid function and the metabolic state of the patient are conditioned by the concentration in plasma of free or unbound, rather than total, $\mathrm{T}_{4}(1,2)$.

\section{Summary}

Studies have been performed in a 66-year-old, postmenopausal female whose serum proteinbound iodine (PBI) was abnormally high despite normal thyroid function and a normal basal metabolic rate. Electrophoretic analyses indicated that the increased PBI was associated with an idiopathic increase in the binding activity of the plasma thyroxine $\left(\mathrm{T}_{4}\right)$-binding globulin (TBG). Although the $\mathrm{T}_{4}$-binding capacity of TBG was in the range usually observed in pregnant patients or those receiving large doses of estrogen, no evidence of endogenous excess of estrogen could be obtained. In the basal state, the increased TBG was associated with an increased PBI and a decreased proportion, but normal concentration, of free $T_{4}$ in the serum. During two separate trials of diethylstilbestrol daily for 3 weeks, none of these functions, including the TBG, changed significantly. During administration of norethandrolone, in contrast, TBG and PBI decreased, the proportion of free $\mathrm{T}_{4}$ increased, but the concentration of free $\mathrm{T}_{4}$-iodine remained normal.

In contrast to the findings with regard to TBG, concentrations of ceruloplasmin and transcortin in the serum were normal in the basal state and increased normally during administration of estrogen.

It is concluded that in this patient, at least, the increase in TBG is not associated with abnormalities in other estrogen-sensitive transport proteins and may be due to an estrogen-independent activation of the same mechanism by which estrogen normally increases TBG.

\section{Acknowledgments}

We are indebted to Miss Nancy A. Dawber for excellent technical assistance and are grateful to Dr. James H. Jandl, Boston, Mass., for analyses of serum iron and iron-binding capacities, to Mrs. Ida Mariz in the laboratory of Dr. William H. Daughaday, St. Louis, Mo., for analyses of plasma cortisol and corticosteroidbinding globulin, and to Dr. I. Herbert Scheinberg, New York, for analyses of ceruloplasmin.

\section{References}

1. Robbins, J., and J. E. Rall. Proteins associated with the thyroid hormones. Physiol. Rev. 1960, 40, 415 .

2. Ingbar, S. H., and N. Freinkel. Regulation of the peripheral metabolism of the thyroid hormones. Recent Progr. Hormone Res. 1960, 16, 353.

3. Beierwaltes, W. H., and J. Robbins. Familial increase in the thyroxine-binding sites in serum alpha globulin. J. clin. Invest. 1959, 38, 1683.

4. Beierwaltes, W. H., E. A. Carr, Jr., and R. L. Hunter. Hereditary increase in the thyroxinebinding sites in the serum alpha-globulin. Trans. Ass. Amer. Phycns 1961, 74, 170.

5. Florsheim, W. H., J. T. Dowling, L. Meister, and R. E. Bodfish. Familial elevation of serum thyroxine-binding capacity. J. clin. Endocr. 1962, 22, 735.

6. Tanaka, S., and P. Starr. A euthyroid man without thyroxine-binding protein. J. clin. Endocr. 1957, $19,485$.

7. Ingbar, S. H. Clinical and physiological observations in a patient with an idiopathic decrease in the thyroxine-binding globulin of plasma. J. clin. Invest. 1961, 40, 2053.

8. Nicoloff, J. T., J. T. Dowling, and D. D. Patton. Inheritance of decreased thyroxine-binding by the thyroxine-binding globulin. J. clin. Endocr. 1964, 24, 294.

9. Scheinberg, I. H., and I. Sternlieb. Copper metabolism. Pharmacol. Rev. 1960, 12, 355.

10. Sandberg, A. A., and W. R. Slaunwhite, Jr. Transcortin: a corticosteroid-binding protein of plasma. II. Levels in various conditions and the effects of estrogens. J. clin. Invest. 1959, 38, 1290. 
11. Slaunwhite, W. R., Jr., and A. A. Sandberg. Transcortin: a corticosteroid-binding protein of plasma. J. clin. Invest. 1959, 38, 384.

12. Sandberg, A. A., W. R. Slaunwhite, Jr., and A. C. Carter. Transcortin: a corticosteroid-binding protein of plasma. III. The effects of various steroids. J. clin. Invest. 1960, 39, 1914.

13. Mills, I. H., H. P. Schedl, P. S. Chen, Jr., and F. C. Bartter. The effect of estrogen administration on the metabolism and protein binding of hydrocortisone. J. clin. Endocr. 1960, 20, 515.

14. Daughaday, W. H., R. E. Adler, I. K. Mariz, and D. C. Rasinski. Measurement of the binding capacity of corticosteroid-binding globulin in human plasma. J. clin. Endocr. 1962, 22, 704.

15. Dowling, J. T., N. Freinkel, and S. H. Ingbar. Thyroxine-binding by sera of pregnant women, newborn infants, and women with spontaneous abortion. J. clin. Invest. 1956, 35, 1263.

16. Dowling, J. T., N. Freinkel, and S. H. Ingbar. Effect of diethylstilbestrol on the binding of thyroxine in serum. J. clin. Endocr. 1956, 16, 1491.

17. Robbins, J., and J. H. Nelson. Thyroxine-binding by serum protein in pregnancy and in the newborn. J. clin. Invest. 1958, 37, 153.
18. Ingbar, S. H., L. E. Braverman, N. Dawber, and G. Y. Lee. A simple method for measuring the free thyroid hormone in serum. Clin. Res. 1964, $12,271$.

19. Benotti, J., and N. Benotti. Protein-bound iodine, total iodine, and butanol-extractable iodine by partial automation. Clin. Chem. 1963, 9, 408.

20. Peterson, R. E., A. Karrer, and S. L. Guerra. Evaluation of Silber-Porter procedure for determination of plasma hydrocortisone. Analyt. Chem. 1957, 29, 144.

21. Scheinberg, I. H., and A. G. Morell. Exchange of ceruloplasmin copper with ionic $\mathrm{Cu}^{64}$ with reference to Wilson's disease. J. clin. Invest. 1957, 36, 1193.

22. Peters, T., T. J. Biovanniello, L. Apt, and J. F. Ross. A new method for the determination of serum iron-binding capacity. I. J. Lab. clin. Med. 1956, 48, 274.

23. Braverman, L. E., and S. H. Ingbar. Unpublished observations.

24. Bothwell, T. H., and C. A. Finch. Plasma transferrin and its iron in Iron Metabolism. Boston, Little, Brown, 1962, p. 138. 